J. Japan. Soc. Hort. Sci. $48(4)$ : 475-482. 1980.

\title{
Cytogenetic Studies on the Origin of Camellia vernalis
}

\author{
I. On the Meiotic Chromosomes in Some Related \\ Camellia Forms in Hirado Island
}

\author{
Shunpei Uemoto, Takayuki Tanaka and Kunimitsu Fujieda \\ Faculty of Agriculture, Kyushu University, Fukuoka 812
}

\begin{abstract}
Summary
In Hirado island, which is situated at the north-western part of Kyushu in Japan, both species of C.japonica and C. sasanqua are distributed together. Recently, certain new forms were found there by Kumazawa and Oda (21), suggesting that some of them could be regarded as varieties of C. vernalis originating in Hirado as natural hybrids between C. sasanqua and C. japonica. In order to approve such a consideration, the authors carried out morphological and cytological surveys in C.vernalis comparing it with C. sasanqua and with C.japonica.

As a result, the authors could recognize one tetraploid and two triploid forms originating in Hirado. The tetraploid form was considered to be the primary hybrid between C. sasanqua (hexaploid) and C.japonica (diploid). One triploid form was considered to be the secondary hybrid between the tetraploid variety and C.japonica, and the other triploid one was supposed to be an auto-triploid form of C.japonica.
\end{abstract}

\section{Introduction}

The first taxonomic description of C. japonica var. vernalis was done by Makino in 1905 (24) using the cultivated variety 'Ginryu'. In 1915, he also came to regard it as an intermediate hybrid species, C.vernalis (Haru-sasanqua), raised between the two parental species, $C$. sasanqua and C.japonica, because characteristics such as leaf size and flowering time of 'Ginryu' took a somewhat intermediate position relative to the above two species (25). Thereafter, about thirty varieties regarded as those of C.vernalis had been discovered in Japan by Kirino $(13,14)$ and Hakoda et al. (8). Many varieties regarded as C.vernalis had already appeared at the Edo-period (1603 1868) in Japan, and some old varieties were named after the local towns in Kyushu, for example ; 'Hirado', 'Kokaji' and 'Koisahaya' (8). The northernmost geographic distribution of wild C.sasanqua is limited to the northern part of Kyushu where C.japonica also grows wild with overlapping of flowering

Received for publication June 12, 1979.

This study was supported in part by a Grant-in -Aid for Scientific Research of the Ministry of Education, Science and Culture. time, so that one of the original localities of C.vernalis should be duly pointed out to be in Kyushu.

On the other hand, cytogenetic studies on chromosome behaviours in Camellia have made an advance recently $(1,2,6,7,10,11,12$, $15,16,17,18,19,20,22,23,26,30)$ and $C$. vernalis was discovered to include two groups of forms, one with 60 and the other with 45 chromosomes, both of which showed the intermediate numbers composed of $C$. japonica $(2 \mathrm{n}=30)$ and C. sasanqua $(2 \mathrm{n}=90)$. From cytological and morphological standpoints, Tashiro and Iwasa (30) considered C.vernalis as a hybrid species raised between $C$. sasanqua and $C$. japonica, and assumed, moreover, that the tetraploid group would belong to the primary hybrid and the triploid group to the secondary one (11).

Recently, Kumazawa and Oda (21) have been surveying on the distribution of Camellia varieties in Hirado and found some original stock plants which may be reckoned as $C$. vernalis. From a historical point of view, they suggested that those stock plants of $C$. vernalis had originated through the natural crosses between wild types of C. sasanqua and C. japonica, and certain red flowering plants 
of C. sasanqua had also originated in Hirado from C.vernalis. The earlier flowering characteristic and higher chromosome number of C. sasanqua could be assumed to be the cause of genetic isolation from C.japonica. Moreover, according to Parks et al. (29), closely related species with the overlapping distributions are more prone to have been provided with much stronger barriers against interspecific hybridization than the allopatric species of similar relationship. In fact, the crossings between both species had been tried out by many workers such as Hilsman (9), Parks et al. (29) and Ackerman (1), but, except for certain special cases, there usually occurred certain difficulties in obtaining hybrid individuals between them.

If many stock plants, which are considered to have been related with the creation of some forms of C.vernalis, had originated in Hirado spontaneously as was suggested by Kumazawa and Oda (21), they will duly suffice to give us an interesting idea not only about the origin of C.vernalis but also concerning the evolution of the genus Camellia. The authors have investigated the chromosome numbers and the meiotic behaviours of chromosomes in PMCs with certain stock plants of C.vernalis which were considered to have originated exclusively in Hirado and with their parental stock plants distributed in the same locality.

\section{Materials and Methods}

All the materials used for the study of mi-
Table 1. List of Camellia in Hirado.

\begin{tabular}{l|l|r|r}
\hline \hline \multicolumn{1}{c|}{ Species } & \multicolumn{1}{|c|}{ Variety } & G. B.* & H.** \\
\hline C. japonica & Chinshin & 45 & 4 \\
& Hirado-oyabu & 58 & 10 \\
C. sasanqua & H-5 & 37 & 3 \\
C. vernalis & Gaisen & 140 & 8 \\
& Sayohime & 55 & 6 \\
\hline
\end{tabular}

* Girth at base $(\mathrm{cm})$.

** Height of tree $(\mathrm{m})$

crosporogenesis had been collected in Hirado. Those stock plants including C.sasanqua, $C$. japonica and C.vernalis are listed in Table 1. In Hirado, the authors were able to recognize not only 4 varietal forms of C.vernalis introduced from other districts of Japan but also 5 varietal forms originating in Hirado and their offspring populations.

Flower-buds collected were fixed and preserved with Newcomer's solution (27). Smear preparations of meristematic anthers were practiced in $1 \%$ aceto-carmine. The chromosome pairing behaviours at diakinesis and at early first metaphase of meiosis were observed. The meiotic data were based on the detailed observations of the chromosome behaviours in PMCs.

\section{Results and Dicussion}

As reported by many workers $(5,6,7,11$ $15,16,17,22,23,26,30)$, the wild forms of C. japonica in Hirado, excepting one stock plant, were also of diploid nature $(2 \mathrm{n}=30)$ and in their meiotic cells fifteen bivalent chromosomes were usually observed. In the stock

Table 2. Characteristics of certain species in genus Camellia in Hirado.

\begin{tabular}{|c|c|c|c|c|c|}
\hline & C. japonica & C. japonica & C.vernalis & C.vernalis & C. sasanqua \\
\hline Variety name & wild type & Hirado-oyabu & Sayohime & Gaisen & wild type \\
\hline Somatic chromosomes $(2 n)$ & 30 & 45 & 45 & 60 & 90 \\
\hline Flower color & red & red & red & red & white \\
\hline Flower form & single & single & single & single & single \\
\hline Stamen form & regular & regular & regular & spreading & spreading \\
\hline Hairs on ovary & glabrous & glabrous & pubescent & pubescent & pubescent \\
\hline Leaf size $\left(\mathrm{cm}^{2}\right)$ & 19.58 & 38.86 & 9.76 & 9.20 & 7.86 \\
\hline Hairs on petiole & glabrous & glabrous & pubescent & pubescent & pubescent \\
\hline $\operatorname{Dots}^{*}\left(/ \mathrm{cm}^{2}\right)$ & 84.58 & 41.56 & 60.86 & 32.83 & 0 \\
\hline Pollen fertility & $99.4(528)^{* *}$ & $39.9(1,031)$ & $11.7(614)$ & $84.7(1,238)$ & $88.7(791)$ \\
\hline Seed set-ability & high & none & none & low & high \\
\hline Blooming period & Mar.-Apr. & Mar.-Apr. & Nov.-Apr. & Nov.-Mar. & Oct.-Nov. \\
\hline
\end{tabular}

* Number of brown dots on the under surface of leaves.

** Number of pollen grains observed. 
Table 3. Chromosome pairings at meiotic division in PMCs of C. japonica 'Chinshin'.

\begin{tabular}{|c|c|c|c|}
\hline \multirow{2}{*}{ Configurations } & \multicolumn{2}{|c|}{ Freqency of PMCs $(\%)$} & \multirow{2}{*}{ Total $(\%)$} \\
\hline & Diakinesis & Metaphase-1 & \\
\hline $15_{\text {II }}$ & $119(99.2)$ & $50(100)$ & $169(99.4)$ \\
\hline $14_{\text {II }}+21$ & $1(0.8)$ & $1 \quad(0)$ & $1(0.6)$ \\
\hline Total & $120(100)$ & $50(100)$ & 170 (100) \\
\hline
\end{tabular}

Table 4. Chromosome pairings at meiotic division in PMCs of C. sasanqua, stock number ' $\mathrm{H}-5$ '.

\begin{tabular}{|c|c|c|c|}
\hline \multirow{2}{*}{ Configurations } & \multicolumn{2}{|c|}{ Freqency of PMCs (\%) } & \multirow{2}{*}{ Total $(\%)$} \\
\hline & Diakinesis & Metaphase- 1 & \\
\hline $45_{\text {II }}$ & $6(85.7)$ & $13(92.9)$ & $19(90.5)$ \\
\hline $44_{\text {II }}+2$ I & $1(14.3)$ & 1 (7.1) & $2(9.5)$ \\
\hline Total & $7 \quad(100)$ & $14(100)$ & $21 \quad(100)$ \\
\hline
\end{tabular}

plant 'Chinshin' of C. japonica originated in Hirado, the pairing behaviour of meiotic chromosomes was also found to be quite normal $\left(2 \mathrm{n}=15_{\text {II }}\right)$ at both stages of diakinesis and metaphase-1 (Table 3, Fig. 1). The pollen fertility of these plants was very high and the seed set ability was relatively high (Table 2 ).

The data concerning chromosome associations of C. sasanqua (stock number ' $\mathrm{H}-5$ ') at both stages of diakinesis and metaphase-1 in PMCs are given in Table 4 . Though this stock plant was not taken as a real wild type of C. $s a$ sanqua, as shown in Fig. 2, 45 bivalent chromosomes were recognized at both stages of diakinesis and metaphase -1 of meiosis in this plant. The chromosome numbers of certain cultivated forms of C. sasanqua have hitherto been reported to be $2 \mathrm{n}=75,90,105$ and 120 by Ito et al. (10) and by Kondo (17). But most of the wild forms in Japan have been considered, in turn, to have exclusively 90 chromosomes in somatic cells. Therefore, so far as this form $(2 \mathrm{n}=90)$ is concerned, C. sasanqua may be well assumed to be an allohexaploid form consisting of three genomes though it is rather difficult to judge from this result only how these genomes are different from each other. Moreover, as reported by Kondo $(15,18)$, C. sasanqua might be a segmental allo-hexaploid in which a large number of homologous segments were distributed throughout the genomes.

Several new stock plants regarded as $C$. vernalis were discovered in Hirado by Kumazawa and Oda (21). Among these plants, a
Table 5. Chromosome pairings at meiotic division in PMCs of C.vernalis 'Gaisen'.

\begin{tabular}{|c|c|c|c|}
\hline \multirow{2}{*}{ Configurations } & \multicolumn{2}{|c|}{ Frequency of PMCs (\%) } & \multirow{2}{*}{ Total $(\%)$} \\
\hline & Diakinesis & Metaphase-1 & \\
\hline $30_{\mathrm{II}}$ & $37(75.5)$ & $8(61.5)$ & $45(72.6)$ \\
\hline $29_{I I}+2 \mathrm{I}$ & $11(22.4)$ & $4(30.8)$ & $15(24.2)$ \\
\hline $28_{11}+4_{1}$ & $1 \quad(2.0)$ & $1 \quad(7.7)$ & $2 \quad(3.2)$ \\
\hline Total & $49 \quad(100)$ & $13(100)$ & $62 \quad(100)$ \\
\hline
\end{tabular}

certain stock plant named 'Gaisen' was found to be tetraploid. The general tendency of configuration of 'Gaisen' at diakinesis and metaphase- 1 of meiosis in PMCs was $30_{\text {II }}$, and some univalent chromosomes were observed (Table 5, Fig. 3). As the fertility of this stock plant was rather high, some seedlings from this plant were able to be gained and to keep alive in a vigorous state. American research workers of Camellia (28) regarded tetraploid varieties as C.hiemalis, but inJapan tetraploid varieties such as 'Egao', 'Umegaka' and others were regarded as C.vernalis. In the present paper, the authors define that C.vernalis is a species of hybrid origin between C. sasanqua and C. japonica, including not only triploid species but also tetraploid species. It may be assumed from the following facts that 'Gaisen' is a primary hybrid raised between C. sasanqua and C. japonica in Hirado, viz.; 1) Some morphological characteristics of 'Gaisen' were intermediate between C.sasan$q u a$ and C.japonica; 2) One of the stock trees of 'Gaisen' in Hirado was considered to be the oldest tree of C. vernalis in Japan, being about 400 years old ; 3 ) In Hirado, the authors were able to find a number of flowers of C.japonica in late November when $C$. sasanqua were still blooming, so that it had been considered that the procedures of primary hybridization between them had been done there: 4) In an oldest book titled 'ChikaZufu', the old cultivated variety 'Hiradosasanqua' which could be regarded as $C$.vernalis was described; 5) Furthermore, judging from the chromosome number, 'Gaisen' $(2 \mathrm{n}=$ 60) was considered to be a primary hybrid raised between $C$. sasanqua $(2 \mathrm{n}=90)$ and $C$. japonica $(2 \mathrm{n}=30)$.

Triploid plants of two different species were also discovered in Hirado. One was named 'Sayohime' which showed some intermediate 


$$
\therefore:-1 ;-
$$

$1-\mathrm{a}$

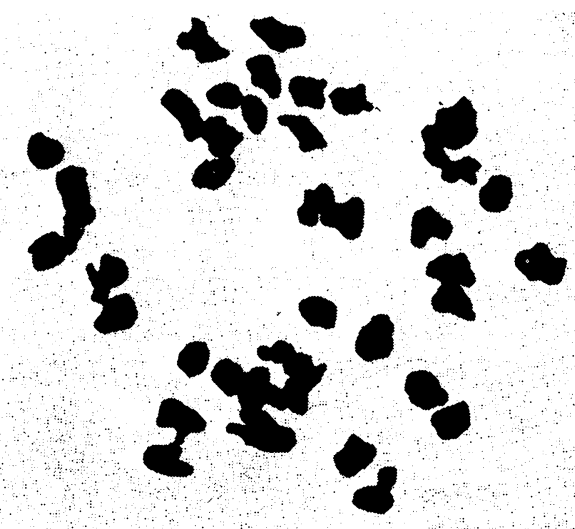

$2-\mathrm{a}$

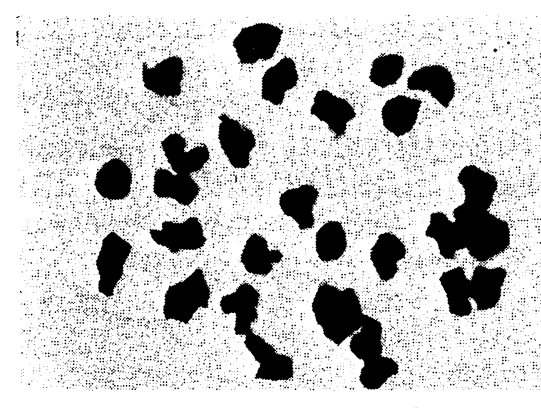

3- a

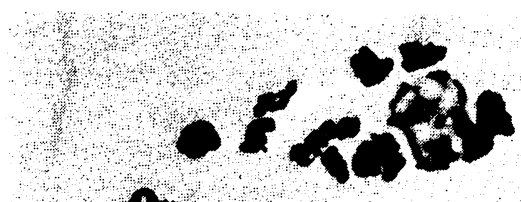

$a_{0}^{0}, 4$

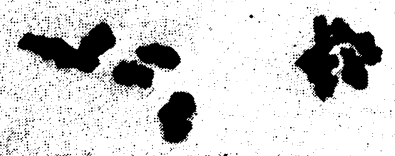

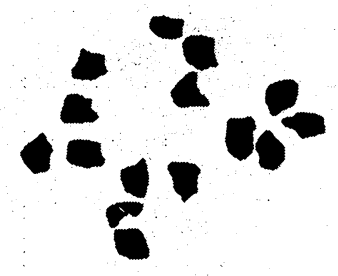

$1-b$

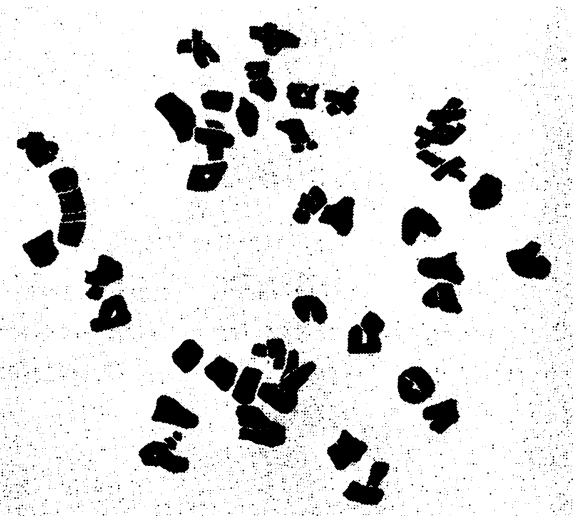

$2-b$

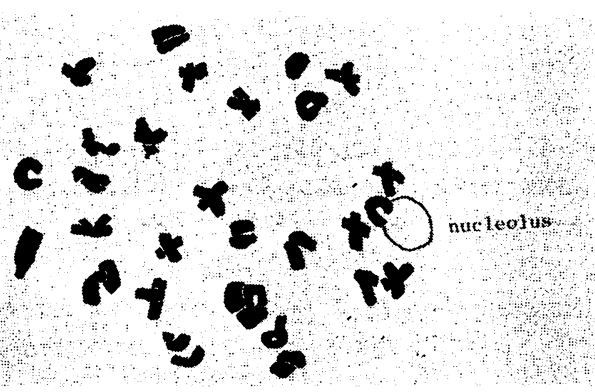

3-b
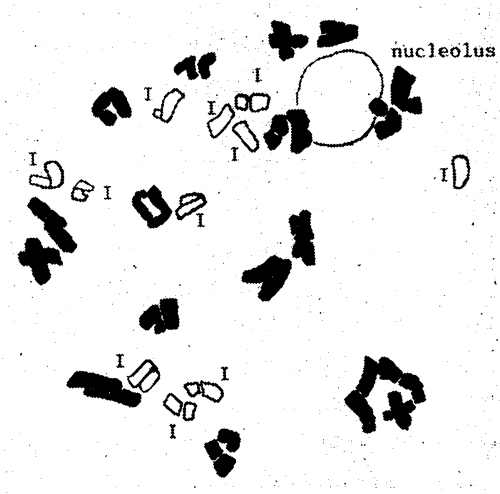

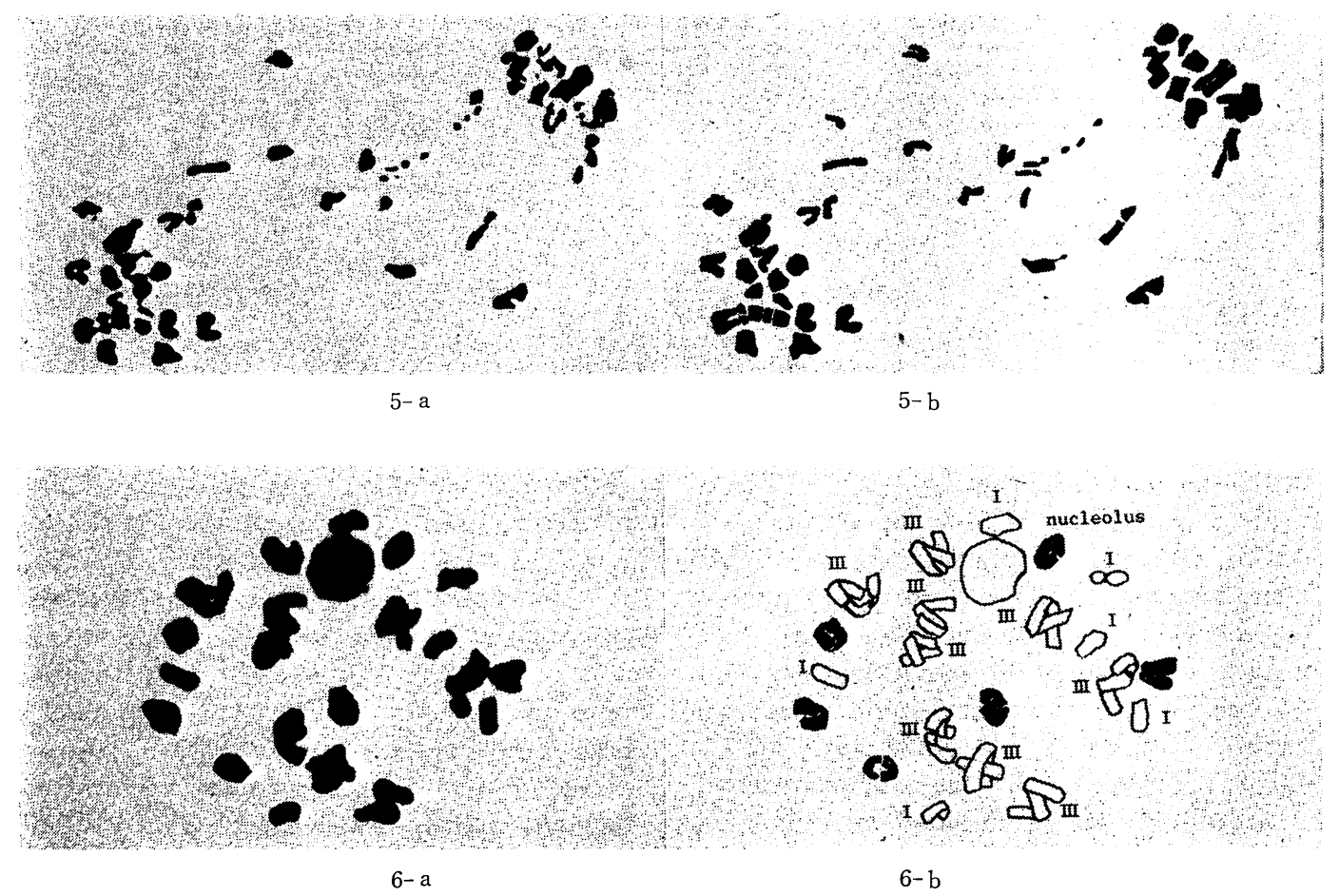

Figs. 1 6. Meiotic chromosomes in PMCs of Camellia $(\times 600)$. a : by microphotography; b : by drawing

Fig. 1. C. japonica 'Chinshin' at early metaphase-1, $2 \mathrm{n}=15_{\mathrm{II}}$.

Fig. 2. C. sasanqua stock number ' $\mathrm{H}-5$ ' at early metaphase-1, $2 \mathrm{n}=45_{\mathrm{II}}$.

Fig. 3. C.vernalis 'Gaisen' at diakinesis, $2 \mathrm{n}=30_{\mathrm{II}}$.

Fig. 4. C.vernalis 'Sayohime' at diakinesis, $2 \mathrm{n}=17_{\mathrm{II}}+11_{\mathrm{I}}$.

Fig. 5. C.vernalis 'Sayohime' at anaphase-1, 13 lagging chromsomes are observed.

Fig. 6. C. japonica 'Hirado-oyabu' at diakinesis, $2 \mathrm{n}=9_{\mathrm{III}}+6_{\mathrm{II}}+6_{\mathrm{I}}$.

Table 6. Chromosome pairings at meiotic division in PMCs of C.vernalis 'Sayohime'.

\begin{tabular}{|c|c|c|c|}
\hline \multirow{2}{*}{ Configurations } & \multicolumn{2}{|c|}{ Frequency of PMCs $(\%)$} & \multirow{2}{*}{ Total $(\%)$} \\
\hline & Diakinesis & Metaphase-1 & \\
\hline $1_{\mathrm{III}}+16_{\mathrm{II}}+10_{\mathrm{I}}$ & $0 \quad(0.0)$ & $1(5.9)$ & $1(3.4)$ \\
\hline $1_{\mathrm{III}}+14_{\mathrm{II}}+14_{\mathrm{I}}$ & $2(16.7)$ & $0 \quad(0.0)$ & $2(6.9)$ \\
\hline $1_{I I I}+11_{I I}+20_{I}$ & $0 \quad(0.0)$ & $1(5.9)$ & $1(3.4)$ \\
\hline $19_{\mathrm{II}}+7_{\mathrm{I}}$ & $0 \quad(0.0)$ & $1(5.9)$ & $1(3.4)$ \\
\hline $18_{\mathrm{II}}+9_{\mathrm{I}}$ & 1 (8.3) & $1(5.9)$ & $2(6.9)$ \\
\hline $17_{\mathrm{II}}+11_{\mathrm{I}}$ & $0 \quad(0.0)$ & $2(11.8)$ & $2(6.9)$ \\
\hline $16_{\mathrm{II}}+13_{\mathrm{I}}$ & $3(25.0)$ & $5(29.4)$ & $8(27.6)$ \\
\hline $15_{\mathrm{II}}+15_{\mathrm{I}}$ & $5(41.7)$ & $1(5.9)$ & $6(20.7)$ \\
\hline $14_{\mathrm{II}}+17_{\mathrm{I}}$ & $1(8.3)$ & $4(23.5)$ & $5(17.2)$ \\
\hline $13_{\mathrm{II}}+19_{\mathrm{I}}$ & $0 \quad(0.0)$ & $1(5.9)$ & 1 (3.4) \\
\hline Total & $12(100)$ & 17 (100) & $29 \quad(100)$ \\
\hline
\end{tabular}

characteristics between 'Gaisen' (C.vernalis) and a certain wild form of C. japonica. The other one was C.japonica 'Hirado-Ōyabu' named by Kumazawa which had larger leaves and flowers than the typical C. japonica. The
Table 7. Chromosome pairings at meiotic division in PMCs of C. japonica 'Hirado-ōyabu'.

\begin{tabular}{|c|c|c|c|}
\hline \multirow{2}{*}{ Configurations } & \multicolumn{2}{|c|}{ Frequency of PMCs (\%) } & \multirow{2}{*}{ Total $(\%)$} \\
\hline & Diakinesis & Metaphase-1 & \\
\hline $1_{\mathrm{IV}}+13_{\mathrm{III}}+1_{\mathrm{II}}$ & $0 \quad(0.0)$ & $1(5.6)$ & $1 \quad(4.5)$ \\
\hline $14_{\mathrm{III}}+3_{\mathrm{I}}$ & $0 \quad(0.0)$ & $1(5.6)$ & $1(4.5)$ \\
\hline $13_{I I I}+3_{I I}$ & $1(25.0)$ & $1(5.6)$ & $2(9.1)$ \\
\hline $13_{\mathrm{III}}+2_{\mathrm{II}}+2_{\mathrm{I}}$ & $0 \quad(0.0)$ & $4(22.2)$ & $4(18.2)$ \\
\hline $12_{\mathrm{III}}+{ }_{\mathrm{I}} 3_{\mathrm{I}}+3_{\mathrm{I}}$ & $1(25.0)$ & $0 \quad(0.0)$ & $1(4.5)$ \\
\hline $11_{\text {III }}+5_{\text {II }}+2_{\text {I }}$ & $0 \quad(0.0)$ & $1(5.6)$ & $1(4.5)$ \\
\hline $11_{\mathrm{III}}+4_{\mathrm{II}}+4_{\mathrm{I}}$ & $0 \quad(0.0)$ & $3(16.7)$ & $3(13.6)$ \\
\hline $11_{I I I}+3_{I I}+6_{I}$ & $1(25.0)$ & $0 \quad(0.0)$ & 1 (4.5) \\
\hline $10_{\mathrm{III}}+5_{\mathrm{II}}+5_{\mathrm{II}}$ & $0 \quad(0.0)$ & $4(22.2)$ & $4(18.2)$ \\
\hline $9_{\text {III }}+7_{\text {II }}+4_{I}$ & $0 \quad(0.0)$ & $1 \quad(5.6)$ & $1 \quad(4.5)$ \\
\hline $9_{\text {III }}+6_{I I}+6_{I}$ & $1(25.0)$ & $0 \quad(0.0)$ & $1(4.5)$ \\
\hline $8_{\mathrm{III}}+8_{\mathrm{II}}+5_{\mathrm{I}}$ & $0 \quad(0.0)$ & $1(5.6)$ & $1(4.5)$ \\
\hline $8_{\text {III }}+7_{\text {II }}+7_{\mathrm{I}}$ & $0 \quad(0.0)$ & $1(5.6)$ & $1(4.5)$ \\
\hline Total & $4 \quad(100)$ & $18(100)$ & $22 \quad(100)$ \\
\hline
\end{tabular}

comparative study of chromosome pairings at meiosis revealed a significant difference between these two triploid plants. In the for- 
Table 8. Average configurations at meiotic division in PMCs of different species of genus Camellia in Hirado.

\begin{tabular}{c|l|r|r|r}
\hline Species & Variety & $2 \mathrm{n}$ & Configurations & PMCs* \\
\hline C. japonica & Chinshin & 30 & $14.99_{\mathrm{II}}+0.01_{\mathrm{I}}$ & 170 \\
& Hirado-oyabu & 45 & $0.05_{\mathrm{IV}}+11.18_{\mathrm{III}}+3.91_{\mathrm{II}}+3.45_{\mathrm{I}}$ & 22 \\
C.vernalis & Sayohime & 45 & $0.14_{\mathrm{III}}+15.34_{\mathrm{II}}+13.90_{\mathrm{I}}$ & 29 \\
& Gaisen & 60 & $29.69_{\mathrm{II}}+0.61_{\mathrm{I}}$ & 62 \\
C. sasanqua & $\mathrm{H}-5$ & 90 & $44.90_{\mathrm{II}}+0.19_{\mathrm{I}}$ & 21 \\
\hline
\end{tabular}

* Number of PMCs observed.

mer, considerably many univalent chromosomes were observed at meiosis (Table 6, Fig. 4) and the most common configuration at diakinesis in PMCs was $15_{\mathrm{II}}+15_{\mathrm{I}}$. Thus, 'Sayohime' was assumed to be an allo-triploid consisting of a pair of similar but somewhat different genomes. Judging from the number of chromosomes and the morphological characteristics of the plant, it was considered that 'Sayohime' was a secondary hybrid between C.vernalis 'Gaisen' and a wild type of $C$. japonica in Hirado. So, it was considered that 'Sayohime' was understood to be a form belonging to the triploid group of C.vernalis. At stages of anaphase- 1 and telophase-1, some laggards and chromatid bridges were observed (Fig. 5), and also this stock plant showed high pollen sterility, never obtaining any seed. Conversely, 'Hirado-Ōyabu' displayed more than eight trivalent formation (Table 7 , Fig. 6) at diakinesis and metaphase- 1 of meiosis in PMCs, and the pollen fertility was rather high (39.9\%). From this data, 'Hirado-oyabu' was considered to be an autotriploid of $C$. japonica. In Hirado, no tetraploid varieties have been met with so far in C.japonica, so that the origin of this triploid C. japonica will presumably be traceable to the rare conjugation of a diploid gamate with an ordinary haploid one $(6,7)$.

The average configurations in PMCs of Camellia plants observed in this study are given in Table 8 . It may be assumed that one pair of genomes of C.sasanqua was not so different from that of C. japonica, because the configuration in PMCs of 'Gaisen', which was considered to be a primary hybrid between them from a viewpoint of characteristics and chromosome number, was composed of almost bivalents, and the configuration of 'Sayohime', a back cross hybrid with C. japonica, was composed of nearly the same number of bivalents and univalents. According to Kondo's reports $(15,19)$, in eight hybrid combinations of Camellia raised between diploid and hexaploid species, thirty bivalents were observed as the most common configuration at metaphase- 1 and he supposed that hexaploid C. sasanqua would carry one genome like that of C.japonica. If the genome of C.japonica is presupposed as AA and that of C.sasanqua as $\mathrm{A}^{\prime} \mathrm{A}^{\prime} \mathrm{BBB}^{\prime} \mathrm{B}^{\prime}$, the primary hybrid between them will have the genome constitution of $\mathrm{AA}^{\prime} \mathrm{BB}^{\prime}$ and the back cross hybrid with $C$. japonica will have that of $\mathrm{AAB}-\mathrm{AA}^{\prime} \mathrm{B}^{\prime}$. On the other hand, as C.vernalis 'Gaisen' displayed $30_{\text {II }}$ and 'Sayohime' displayed $15_{\text {II }}+15_{\text {I }}$, the genome constitutions of these cultivated varieties could be presumed as $A A B B$ and $A A B$ respectively. Thus, C.vernalis 'Gaisen' will be a primary hybrid between C. sasanqua and C. japonica, and 'Sayohime' will be a secondary hybrid between C.vernalis 'Gaisen' and C. japonica. Origin or synthetic processes of these C.vernalis formulated from morphological and cytological viewpoints are reproduced in Fig. 7 as a schematic diagram.

In horticultural varieties regarded as $C$. vernalis, there are a number of triploid varieties such as 'Ginryu', 'Shokko-nishiki', 'Kyo-ni-

$$
\begin{aligned}
& \text { C. sasanqua, } \mathrm{A}^{\prime} \mathrm{A}^{\prime} \mathrm{BBB}^{\prime} \mathrm{B}^{\prime} \mathrm{X} \text { C. japonica, } \mathrm{AA} \\
& \text { (wild form, } 2 \mathrm{n}=45_{\mathrm{Il}} \text { ) } \downarrow \text { (wild form, } 2 \mathrm{n}=15_{\mathrm{II}} \text { ) } \\
& \text { C.vernalis, } \mathrm{AA}^{\prime} \mathrm{BB}^{\prime} \quad \mathrm{X} \text { C.japonica, } \mathrm{AA} \\
& \text { ('Gaisen', } 2 \mathrm{n}=30_{\mathrm{II}} \text { ) } \downarrow \text { (wild form, } 2 \mathrm{n}=15_{\mathrm{HI}} \text { ) } \\
& \text { C. vernalis, } \mathrm{AAB}-\mathrm{AA}^{\prime} \mathrm{B}^{\prime} \\
& \text { ('Sayohime', } 2 \mathrm{n}=15_{\mathrm{II}}+15_{\mathrm{I}} \text { ) }
\end{aligned}
$$

Fig. 7. Schematic diagram of probable origin of C.vernalis in Hirado. 
shiki', 'Yamato-nishiki', 'Kamakura-shibori', 'Hisatomi' (unpublished) and so on. Recently, the authors have found some tetraploid cultivars allied to 'Gaisen' such as 'Showanokagayaki', 'Yōkihi' and others. But in the other districts of Japan except Hirado, interrelationships between triploid and tetraploid species of C.vernalis have not yet been so clear.

Most varieties of C.vernalis have certain noticeable characteristics and they are duly expected to show much wider variations. But until now, no new artificial forms of C.vernalis have yet been raised, because it is not easy to breed up hybrid individuals between C. sasanqua and C. japonica, and also triploid C.vernalis has a rather rare seed set. The cultivated variety 'Gaisen' showed, however, rather high cross-compatibility with C. sasan$q u a$ and C.japonica (unpublished) and the flowering time of 'Gaisen' occurs during the period from November through March, so that it will become rather easy to cross with not only C.sasanqua but also with C.japonica. Furthermore, if the cultivated variety 'Gaisen' is a primary hybrid between C.sasanqua and C. japonica as is presumed in the present paper, its offsprings will be considered to be the segregating generation. Thus, 'Gaisen' will become an important variety as the seed parent for raising new forms of C.vernalis. The authors have been making further studies to make clearer the origin of C.vernalis using a large number of artificial cross combinations of Camellia forms.

\section{Acknowledgement}

The authors wish to express their sincere appreciations to Dr. Eiji Fukushima, Emer. Prof. of Kyushu Univeristy, for his valuable guidance, helpful suggestions and for reading the manuscript. Thanks are also due to $\mathrm{Mr}$. Kumazawa, former director of Kyushu Agricultural Experiment Station, for his helpful suggestions given to the authors.

\section{Literature Cited}

1. ACKerman, W.L. 1970 Interspecific hybridization of Camellia. Amer. Camellia Yearb. $1970: 65-79$

2. ACKerman, W. L. 1973 a. Aneuploidy in the Camellia. J. Hered. $64:$ 197-202.

3. ACKERMAN, W.L. 1973 b. Species compatibility relationships within the genus Camellia. J. Hered. $64: 356-358$.

4. ACKERMAN, W. L. and H. DERMAN. 1972. A fertile colchiploid from a sterile interspecific Camellia hybrid. J. Hered. 63 : 55-59.

5. BeZBARUAH, H. P. 1971. Cytological investigations in the family Theaceae. I. Chromosome numbers in some Camellia species and allied genera. Caryologia $24: 421-426$.

6. Fukushima. E., S. IWASA, N. Endo and T. YOSHINARI. 1966. Cytogenetic studies in Camellia. I. Chromosome survey in some Camellia species. J. Japan. Soc. Hort. Sci. 35 : 413-421.

7. FukUshima, E. and S. IwasA. 1968. Cytological studies in Camellia. In "Camellia of Japan" ed. by T. Tsuyama, Takeda Science Foundation Osaka, Hirokawa Publishing Co.,Ltd. Tokyo.: pp. 33-44.

8. HAKOdA, N.J. TAKENAGA and M. MATSUMOTO. 1974. Historical studies on the variety differentiation of C. sasanqua. Bulletin of the Farms Tokyo University of Agriculture and Technology. $6: 1-65+4 \mathrm{pl}$.

9. HILSMAN, P. L. 1966. Interspecific Camellia hybrids. Amer. Camellia yearb. 1966 : 113142.

10. ITO, H., E, FukUshima and K, ARIzUmi. 1957. On the differentiation of the garden varieties in the genus Camellia. II. C. sasanqua and its allied species. Abstract of 1957 autumn meeting, Japan. Soc. Hort. Sci.: 18-19. (in Japanese).

11. IWASA, S. 1971. Cytogenetic studies in Camellia. The Heredity. $25(2): 14-19$. (in Japanese).

12. Kato, M. and T. SimurA. 1978. Cytogenetical studies on Camellia species. III. An interspecific hybrid between Camellia japonica $\mathrm{L}$. and C. sinensis (L.) O. Kunze. Japan. J. Breed. 28(2) : 147-150.

13. KIRINO, S. 1970. Introduction of literature and morphological studies on C. vernalis. Special number on Camellia of Kyoto Engei Club. $10: 17-54$. (in Japanese).

14. KIRINO, S. 1972 On the horticultural vatieties of C. vernalis. Tsubaki $11: 50-57$ (in Japanese).

15. KoNDO, K. 1975. Cytological studies in cultivated species of Camellia. ph. D. Dissertation, Univ. N. Carolina, Chapel Hill : pp. $260+$ $\mathrm{x}$.

16. Kondo, K. 1977 a. Cytological studies in cultivated species of Camellia. I. Diploid species and their hybrids. Japan. J. Breed. 27 (1) : 28 -38 . 
17. KONDO, K. 1977 b. Chromosome numbers in the genus Camellia. Biotropica 9(2) : 86-94.

18. KonDO, K. 1977 c. Cytological studies in cultivated species of Camellia. II. Hexaploid species and their hybrids. Japan. J. Breed. 27 (4) : 333-344.

19. KONDO, K. 1978. Cytological studies in cultivated species of Camellia. III. Tetraploid species and hybrids between diploid species and hexaploid species. Japan. J. Breed. 28 (3) : 197-204.

20. KONDO, K. H. SANO and M. SAGAWA. 1978. Karyotypes in triploid and tetraploid clones of C. sinensis. CIS $24: 14-16$.

21. KumazAWA, S. and M. ODA. 1978. Wild C.japonica and original C. sasanqua in Hirado. Garden Life $3: 67-78$. (in Japanese).

22. LONGley, A. E. and E. C. TOURJE. 1959. Chromosome numbers of certain Camellia species and allied genera. Amer. Camellia Yearb. 1959 : 33-39.

23. Longley, A. E. and E. C. TourJe. 1960. Chromosome numbers of certain Camellia species and allied genera. Amer. Camellia yearb. $1960: 70-72$.

24. MAKINO, T. 1905. Observations on the Flora of Japan. Bot. Mag. Tokyo $19: 135-136$.

25. MAKINO, T. 1915. A contribution to the knowledge of the flora of Japan. Jour. Jap. Bot. 1 (12) $: 40$.

26. Morinaga, T. and E. FukUshima. 1931. Chromosome numbers of cultivated plants III. Bot. Mag. Tokyo 45 : 140-145.

27. Newcomer, H. 1953. A new cytological and histological fixing fluid. Science $118: 161$.

28. PARKS, C.R. 1968. A listing of interspecific Camellia hybrids developed at the Los Angeles State and County Arboretum. Amer. Camellia Yearb. 1968 : 266-282.

29. PARKS, C. R.,A. GRIFFITHS, JR. and K. R. MONTOGOMERY. 1968. A possible origin of anthocyanin (red) pigmentation in the flowers of Camellia sasanqua. Amer. Camellia yearb. $1968: 229-242$.

30. TASHIRO, Y. and S. IWASA. 1972. Cytological studies in Camellia. II. On the varieties of C. vernalis. Abstract of 1972 Spring Meeting, Japan. Soc. Hort. Sci. 14-15. (in Japanese).

31. Watanabe, T. (ed.) 1969. Chinka Zufu, Japanese Camellias the Imperial Collection. Kōdansha, Tokyo.

\title{
ハルサザンカの起原に関する細胞遺伝学的研究（第 1 報） \\ 平戸における数種ツバキ属植物の減数分裂染色体について \\ 上本 俊平・田中 孝幸・藤枝 國光 \\ (九州大学農学部)
}

\begin{abstract}
摘 要
九州の北西部に位置する平戸島には，ヤブシバキとサ ザンカが野生的に共存しており, 最近, 熊澤及び小田 (21)によって，それらの間の自然雑種と見られる数株が 見出された．これらはいずれもハルサザンカの範ちゅう に入れられるべき諸形質を示している．著者らは，それ らと同時に見出されたシバキの同質倍数体と考兄られる 株とともに，その成立過程を解明するため，形態的，ま た細胞遺伝学的調查を行った.

3 倍体 2 株を明らかにした，4 倍体はサザンカ（6x）と ヤブッバキ $(2 \mathrm{x})$ との間の一次雑種とみなされ，3倍体 株のうち 1 株は, 前記 4 倍体ハルサザンカとヤブッバキ との交雑に起因する 2 次雑種と考光られ, 他の 1 株はヤ ブッバキの同質 3 倍体であった．それらは熊澤及び小田 によって，それぞれ ‘凱旋（がいせん）， ‘佐用媛（さ よひめ)’及び ‘平戸大簌 (ひらど拈おやぶ)’ と命名され ている.
\end{abstract}

その結果, シバキ属の倍数系列から見て 4 倍体 1 株と 